\title{
Amplified bioproductivity during Transition IV (332 000-342 000 yr ago): evidence from the geochemical record of Lake El'gygytgyn
}

\author{
L. Cunningham ${ }^{1, *}$, H. Vogel ${ }^{2,3}$, V. Wennrich ${ }^{2}$, O. Juschus ${ }^{2}$, N. Nowaczyk ${ }^{4}$, and P. Rosén ${ }^{1}$ \\ ${ }^{1}$ Climate Impacts Research Centre (CIRC), Umeå University, 98107 Abisko, Sweden \\ ${ }^{2}$ University of Cologne, Institute of Geology and Mineralogy, Zuelpicher Str. 49a, 0674 Cologne, Germany \\ ${ }^{3}$ University of Bern, Institute of Geological Sciences and Oeschger Centre for Climate Change Research, Baltzerstr. $1+3$, \\ 3012 Bern, Switzerland \\ ${ }^{4}$ GeoForschungsZentrum Potsdam, Section 3.3, Telegrafenberg, 14473 Potsdam, Germany \\ *now at: Department of Geography and Geosciences, University of St Andrews, St Andrews, Fife KY16 9AL, Scotland, UK
}

Correspondence to: L. Cunningham (1kc10@st-andrews.ac.uk)

Received: 19 October 2012 - Published in Clim. Past Discuss.: 5 November 2012

Revised: 14 February 2013 - Accepted: 24 February 2013 - Published: 14 March 2013

\begin{abstract}
To date, terrestrial archives of long-term climatic change within the Arctic have widely been restricted to ice cores from Greenland and, more recently, sediments from Lake El'gygytgyn in northeast Arctic Russia. Sediments from this lake contain a paleoclimate record of glacialinterglacial cycles during the last three million years. Lowresolution studies at this lake have suggested that changes observed during Transition IV (the transition from marine isotope stage (MIS) 10 to MIS 9) are of greater amplitude than any observed since. In this study, geochemical parameters are used to infer past climatic conditions thus providing the first high-resolution analyses of Transition IV from a terrestrial Arctic setting. These results demonstrate that a significant shift in climate was subsequently followed by a rapid increase in biogenic silica $(\mathrm{BSi})$ production. Following this sharp increase, bioproductivity remained high, but variable, for over a thousand years. This study reveals differences in the timing and magnitude of change within the ratio of silica to titanium ( $\mathrm{Si} / \mathrm{Ti}$ ) and $\mathrm{BSi}$ records that would not be apparent in lower resolution studies. This has significant implications for the increasingly common use of $\mathrm{Si} / \mathrm{Ti}$ data as an alternative to traditional BSi measurements.
\end{abstract}

\section{Introduction}

Recent rapid warming observed within the latter part of the 20th century has raised many questions about the rate at which global climate can change. Paleoclimatic data from a variety of proxies have demonstrated multiple, rapid shifts in climate have punctuated earth's history. For example, icecore records from the Younger Dryas in Greenland indicate a $10^{\circ} \mathrm{C}$ increase in temperature within a decade (Alley, 2000). Furthermore, abrupt climatic changes have been shown to occur repeatedly throughout the past $500000 \mathrm{yr}$ (Oppo et al., 1998). That abrupt climate changes can, and have occurred, is now accepted, however, there is a need for an increased understanding of such changes, the rate at which they occur, and modelling to understand the mechanisms behind such changes. These data will inform us of essential information for predicting tuning climate models used for predicting future climate change.

The need for high-resolution paleoclimate records is especially urgent for high latitude regions as they are increasingly subject to physical perturbation by both anthropogenic disturbance and climatic change. Polar regions are expected to experience the greatest and most rapid climatic changes of any region on earth (IPCC, 2007). In addition, polar regions can exert a significant influence on global climates, primarily through surface reflectivity, freshwater influence on ocean currents and the release of greenhouse gases (ACIA, 2004). These feedback mechanisms are generally expected to amplify global warming (Holland and Bitz, 2003), however, there is still debate as to the net result (Serreze and Francis, 2006). Thus not only is the Arctic currently subject to the greatest changes in climate, but feedback mechanisms within this region can also influence global climate. 
Currently there are insufficient paleoclimate data from the arctic region to adequately constrain and validate regionalscale models (ACIA, 2004). Few long-term climatic datasets are available, most of which are derived from marine sediments. High-resolution reconstructions from the Arctic Ocean have been hampered due to low sedimentation rates and difficulties with stratigraphic correlation between cores (Bauch and Erlenkeuser, 2008; Bauch et al., 2011). Icecores from Greenland have provided high-resolution terrestrial records of climatic changes however these only cover the past two glacial periods (Johnsen et al., 2001; Sveinbjornsdottir and Johnsen, 2012; Wolff, 2012). High-resolution data of high latitude climatic change over longer timescales is so lacking that models predicting such changes are based on data from the southern hemisphere (Siddall et al., 2006).

Studies of the sedimentary record from Lake El'gygytgyn may help overcome this problem, as it is the longest, continuous, terrestrial record of climate change from the Arctic (Brigham-Grette et al., 2007; Melles et al., 2012). A recent study from this site suggests that climatic changes observed during Transition IV were greater than any others within the last $350000 \mathrm{yr}$ (Frank et al., 2012) as indicated by several proxies including BSi, total organic carbon (TOC) and magnetic susceptibility (MS). A higher resolution study (up to $4 \times$ higher) using these parameters was therefore undertaken to further contribute to our understanding of climate change within this region. Of the sediment characteristics previously examined, BSi, TOC and MS were selected for the current study as these appeared to have the strongest relationship with past climatic conditions. The elemental ratios of $\mathrm{Si} / \mathrm{Ti}$ and iron to manganese $(\mathrm{Mn} / \mathrm{Fe})$ were also incorporated, thereby enabling further assessment of silica input and the dissolution of magnetic minerals, respectively.

$\mathrm{BSi}$ indicates the productivity of silica producing organisms, predominantly diatoms, within aquatic ecosystems. As diatoms are the dominant primary producer in Lake El'gygytgyn, and are strongly influenced by climate (Cremer and Wagner, 2003; Cherapanova et al., 2007), BSi is an ideal indicator of past climatic conditions (Melles et al., 2012). At Lake El'gygytgyn, the sediment record indicates that BSi is positively related to surface air temperatures as increasing temperatures decrease the duration of snow and ice cover on the lake, thus increasing light availability and enhancing primary production. Strong correlations between air temperature and BSi concentrations have previously been shown in lakes from Switzerland (Blass et al., 2007) and Alaska (McKay et al., 2008). The interpretation of BSi as primarily reflecting climatic changes does not, however, exclude the influence of nutrient supply on primary productivity as changes in nutrient supply are also likely to be driven by changes in climate. During glacial periods, there will be limited supply of nutrients into the lake; conversely, in warmer periods there will be increased nutrient supply from the catchment as a result of increased presence of vegetation, soil formation, an increase in the depth of active permafrost layer and enhanced chemical weathering. Warmer temperatures may also promote increased nutrient recycling from the hypolimnion and sediment/water interface. Dissolution of $\mathrm{BSi}$ will also increase with higher temperatures and when more organic material is available (Natori et al., 2006). Dissolution of BSi can be significant in deep continental lakes (Ryves et al., 2003) but is thought to be minimal in case of Lake El'gygytgyn (Melles et al., 2012; Snyder et al., 2012). The BSi record extracted from the sediments represents the integration of all these different processes and variables.

The Si/Ti ratio provides another indicator of biogenic silica production. The total amount of silica within the system is normalised by the amount of titanium (as a proxy for clastic sediment supply), with an increase in the ratio therefore regarded as indicating increased biogenic silica production. This method assumes, however, that both the ratio of $\mathrm{Si} / \mathrm{Ti}$ within the catchment and the amount transported into the lake remain constant. The latter is unlikely to be maintained over glacial cycles however, as the rate of erosion and sediment input will be strongly influenced by the presence or absence of ice cover. Despite this, $\mathrm{Si} / \mathrm{Ti}$ values are highly correlated $\left(R^{2}=0.88 ; n=635\right)$ with Fourier transform infrared spectroscopy (FTIRS) inferred BSi over the past 2.8 Ma (Melles et al., 2012).

The amount of TOC in the sediments reflects primary production and the input of organic matter from the catchment, offset by decomposition of organic matter in the water column and sediments. All three processes typically increase during warm conditions and TOC values therefore represent an interplay between the relative rates of each process (Melles et al., 2007). MS values in El'gygytgyn sediments predominantly reflect the rate of preservation of magnetic mineral phases. Strong degradation of magnetic mineral phases typically occurs when the bottom waters and surface sediments become anoxic, as is the case when the lake is permanently ice covered (Frank et al., 2012). Good preservation typically occurs when the water column and surface sediments are well oxygenated due to annual wind and density driven mixing of the water column, which only takes place if the ice cover disintegrates during summer months (Nowaczyk et al., 2002, 2007). The $\mathrm{Mn} / \mathrm{Fe}$ ratio is another paleoredox indicator with low $\mathrm{Mn} / \mathrm{Fe}$ ratios typically indicating reducing conditions (Loizeau et al., 2001; Melles et al., 2012); however, Fe can be mobilised to the same extent as Mn under severely reduced conditions (Snowball, 1993).

This combination of proxies can provide valuable information about past climatic and environmental conditions. Consequently, a high-resolution study was undertaken to further elucidate the transition into MIS 9 and thus contribute to our understanding of rapid climate change during transitional periods. 


\section{Site description}

Lake El'gygytgyn $\left(67^{\circ} 30^{\prime} \mathrm{N}, 172^{\circ} 05^{\prime} \mathrm{E}\right)$ is situated in northeastern Russia, approximately $100 \mathrm{~km}$ north of the Arctic Circle (Fig. 1). The climate of this region is harsh, with a mean annual temperature of $-10.2^{\circ} \mathrm{C}$ recorded in 2002 (Nolan and Brigham-Grette, 2007). The cold conditions are reflected in the depth of permafrost, which can be up to $300 \mathrm{~m}$ thick (Nolan and Brigham-Grette, 2007). Vegetation within the area is scant, consisting predominantly of lichen and herbaceous taxa, although shrub forms of Salix and Betula are occasionally present in sheltered areas (Lozhkin et al., 2007). The harsh climate also exerts an influence on the lake itself, which remains ice covered for at least nine months of the year (Nolan and Brigham-Grette, 2007).

Lake El'gygytgyn is located within a meteorite crater, believed to have formed 3.6 Ma ago (Layer, 2000). The crater is approximately $18 \mathrm{~km}$ in diameter whilst the lake itself covers an area of $110 \mathrm{~km}^{2}$. A seismic survey has shown that Lake El'gygytgyn contains a generally undisturbed sediment record above impact breccia (Niessen et al., 2007). A scientific drilling operation in spring 2009 recovered the $318 \mathrm{~m}$ thick lake sediment sequence which spans $\sim 2.8$ million years (Melles et al., 2011, 2012). In the current study, we present a high-resolution record of the MIS 10-MIS 9 transition.

\section{Methods}

This study focuses on a $16.6 \mathrm{~m}$ core (Lz1024; 67 $30.13^{\prime} \mathrm{N}$, $\left.172^{\circ} 06.46^{\prime} \mathrm{E}\right)$ spanning $\sim 350 \mathrm{ka}$. A full description of the methods used to retrieve the composite sediment core Lz1024 is given in Melles et al. (2005). Prior to subsampling the core sections were split in half, lengthwise. One half was used for high-resolution X-ray fluorescence (XRF) and MS measurements using the methodology described in Melles et al. (2012), except that XRF analyses had an analysis time of $20 \mathrm{~s}$ per measurement. The counts per second (cps) data obtained from XRF scanning analyses can be used as estimates of the relative concentrations (Croudace et al., 2006). Consequently, the $\mathrm{Mn} / \mathrm{Fe}$ ratio was calculated from the cps data. The $\mathrm{Si} / \mathrm{Ti}$ data incorporated within this study is derived from a longer composite core from Lake El'gygytgyn which has been corrected for the effects of the sediment matrix (Melles et al., 2012). To facilitate comparisons between datasets, block averaging was used to match these higher resolution series (XRF and MS) to the sample resolution of the BSi data.

BSi and TOC concentrations were inferred using FTIRS at $0.25 \mathrm{~cm}$ and $1 \mathrm{~cm}$ resolution, respectively, representing a higher resolution relative to the $2 \mathrm{~cm}$ samples incorporated in Melles et al. (2012). Subsamples for FTIRS analysis were collected between $1620 \mathrm{~cm}$ and $1660 \mathrm{~cm}$ of the core which, based on the chronology (Melles et al., 2012), represents

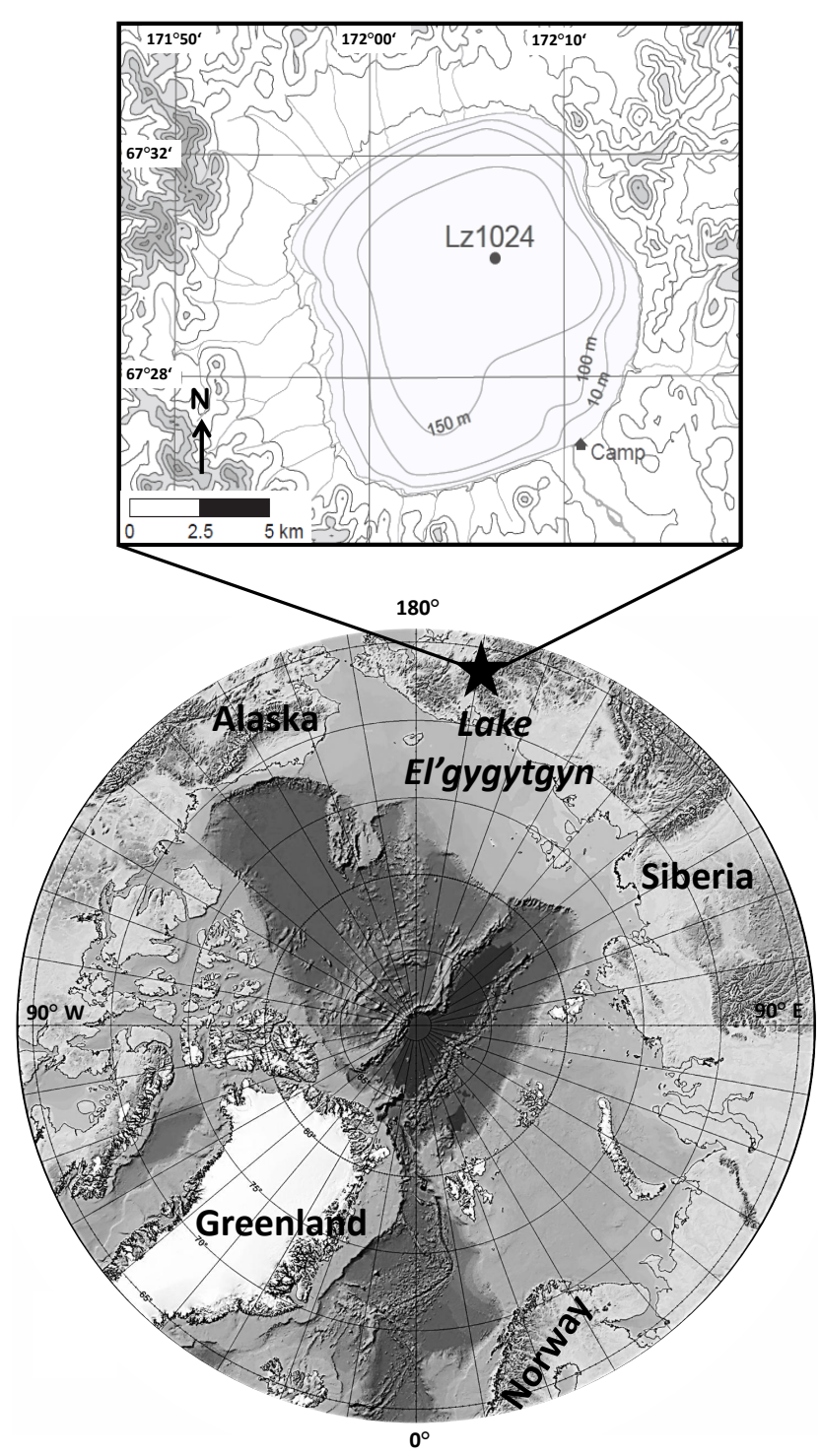

Fig. 1. Map of the Arctic region showing the location of Lake El'gygytgyn. Details of the catchment and coring site are shown in the inset (modified from Nolan and Brigham-Grette, 2007).

Transition IV. The sediment of the sub-sampled section was massive and grey to light brown in colour and contained low but variable amounts of organic matter. FTIRS sample preparation, analysis and model calibration followed Rosén et al. (2011), except that as per Melles et al. (2012) only samples from Lake El'gygytgyn were included in the calibration model, thus following the recommendations of Vogel et al. (2008) for long sedimentary sequences..

The age model for Lake El'gygytgyn, is primarily based on paleomagnetic data and tuning of the proxy record to insolation at $67.5^{\circ} \mathrm{N}$ and the global marine oxygen isotope stack. Dates within the upper section of the core were confirmed by radiocarbon and infrared stimulated luminescence (IRSL) dating (Nowaczyk, personal communication, 2013). As the 
section of the core discussed in this paper is essentially based on tuning of the proxy record to insolation, the ages given may not be accurate in terms of absolute ages. For the time period presented here, there is a potential error of approximately $500 \mathrm{yr}$ for the assigned ages (Nowaczyk, personal communication, 2013). Allowing for this potential inaccuracy of the age model, the section of the core discussed in this paper covers the time period from $\sim 332$ to $\sim 342$ thousand years ago $(\mathrm{ka})$. The temporal resolution for samples varied between $\sim 40$ and $90 \mathrm{yr}$, with an average value of $\sim 60 \mathrm{yr}$. To assess the impact of sediment accumulation rates on the proxy records, we present the datasets both in their original units and standardised by the time period over which each sample accumulated (Fig. 2).

\section{Results and discussion}

\subsection{Description of the proxy records}

In the earliest part of the record the $\mathrm{Mn} / \mathrm{Fe}$ and TOC records show gradual declines (Fig. 2), with minimum values (4.7 cps and $0.2 \%$, respectively) occurring at $\sim 338.5 \mathrm{ka}$. The TOC values remain relatively stable until $\sim 336 \mathrm{ka}$, however, the $\mathrm{Mn} / \mathrm{Fe}$ record is more variable, initially increasing to almost equal the early values at $\sim 336.5 \mathrm{ka}$, then dropping sharply before increasing once more. A sharp increase is noted in both records from $\sim 336 \mathrm{ka}$, although once again the $\mathrm{Mn} / \mathrm{Fe}$ record shows more pronounced variability. In contrast to the $\mathrm{Mn} / \mathrm{Fe}$ record, $\mathrm{MS}$ is stable in the earliest part of the record $(\sim 342 \mathrm{ka}$ to $\sim 340 \mathrm{ka})$ but shows a gradual increase to intermediate values already at $\sim 336.5 \mathrm{ka}$. MS values then decrease, similar to the $\mathrm{Mn} / \mathrm{Fe}$ values, but show a more gradual recovery. The MS values continue to increase until $\sim 334.5 \mathrm{ka}$ when maximum values are reached, coinciding with maximal TOC values and a notable increase in the sediment accumulation rate (SAR). Both MS and TOC values subsequently decrease sharply, with TOC dropping to intermediate values while MS values revert back to levels seen within the early part of the record. The decrease in these parameters probably results from dilution associated with high SAR from both catchment input and high fluxes of autochthonous biogenic silica to the sediment. This interpretation is supported by continuing increase in $\mathrm{Mn} / \mathrm{Fe}$ values which reach maximum values at $\sim 333 \mathrm{ka}$ after which they decrease slightly, but still remain at levels well above that seen during the preceding glacial period. The variability within the $\mathrm{Mn} / \mathrm{Fe}$ data decreases noticeably at $\sim 334.5 \mathrm{ka}$ coinciding with higher SAR, with the decreased variability persisting until the end of this record $(\sim 332 \mathrm{ka})$.

The $\mathrm{Si} / \mathrm{Ti}$ values are variable but low through the first part of the record. The minimum value is recorded at $339.5 \mathrm{ka}$, followed a gradual increasing trend. A small decrease in values is observed at $\sim 335 \mathrm{ka}$; however, values only remain subdued for $\sim 800 \mathrm{yr}$. A marked increase in values is

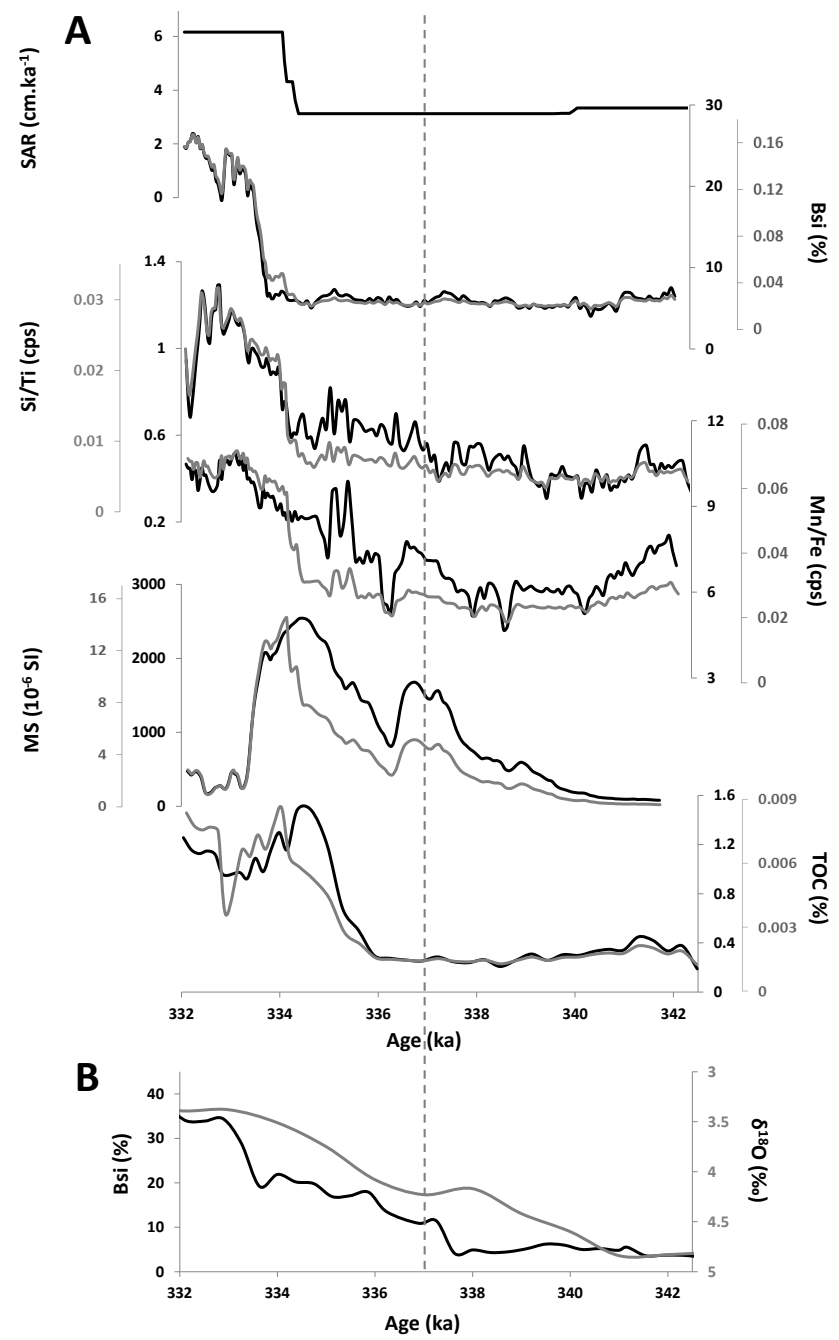

Fig. 2. (A): Sediment accumulation rates (SAR) and high-resolution reconstructions of the geochemical proxies: biogenic silica (BSi), silica/titanium ( $\mathrm{Si} / \mathrm{Ti})$, manganese/iron $(\mathrm{Mn} / \mathrm{Fe})$, magnetic susceptibility (MS) and total organic carbon (TOC) from Lake El'gygytgyn during Termination IV. The black lines indicate the initial proxy data; the grey lines illustrate the proxy series divided by the time period that it took each sample to accumulate. (B): comparisons with the lower resolution biogenic silica record from Lake Baikal (Prokopenko et al., 2006; black line) and the stacked marine $\delta^{18} \mathrm{O}$ record (Lisiecki and Raymo, 2005; grey line) reflect a general synchronicity of timing, given the potential chronological errors associated with these records. The vertical dashed line indicates the timing of boundary between MIS9 and MIS10 suggested by Lisiecki and Raymo (2005).

observed at $\sim 334 \mathrm{ka}$ and values continue to increase until $332.5 \mathrm{ka}$ at which point several pronounced oscillations are observed (Fig. 2). The BSi values are low and relatively stable $(5-8 \%)$ throughout most of the record, until a very sharp increase starts at $\sim 334 \mathrm{ka}$. This suggests a significant lag in the response of the BSi producing communities, relative to the abiotic parameters. Although delayed, 
the response is pronounced as $\mathrm{BSi}$ values more than double within the next $500 \mathrm{yr}$, exceeding $20 \%$. When the data are adjusted for the time period over which each sample accumulated, a smaller increase is observed at $\sim 334.5 \mathrm{ka}$ consistent with other parameters. After the dramatic increase at $\sim 334 \mathrm{ka}$, an increasing trend is apparent within the BSi values. There is a sudden decrease in values at $333 \mathrm{ka}$; however, values again increase from this point, with a maximum value of $26.5 \%$ observed at $\sim 332 \mathrm{ka}$. This potentially coincides with a mid-MIS 9 decrease in productivity and temperature indicated by biomarker data (D'Anjou et al., 2012) however the low temporal resolution of the latter precludes more definitive comparisons.

Given the differences between $\mathrm{BSi}$ and the $\mathrm{Si} / \mathrm{Ti}$ record described above, it is not surprising that the correlation within this time period $\left(r^{2}=0.70\right)$ is weaker than that observed over the entire El'gygytgyn record $\left(r^{2}=0.88\right.$; Melles et al., 2012). The results presented here caution against using $\mathrm{Si} / \mathrm{Ti}$ ratios as an indicator of $\mathrm{BSi}$ until the underlying causes of such differences can be elucidated. For example, the offsets between these two parameters potentially suggest that $\mathrm{Si} / \mathrm{Ti}$ values may be more strongly influenced by either the amount, or grain-size, of catchment material entering the lake than typically expected. Lags between $\mathrm{BSi}$ and $\mathrm{Si} / \mathrm{Ti}$ visible in other records, particularly during warming phases, are typically overlooked due to the strong overall correlation between these proxies (e.g. Brown et al., 2007). Consequently, detailed information regarding the timing of biological responses to climatic change may be lost through the use of $\mathrm{Si} / \mathrm{Ti}$ as a surrogate for $\mathrm{BSi}$. The implications of this are particularly important for high (sub millennial) resolution studies.

\subsection{Climatic interpretation}

The results presented here indicate that the deepest section of the record reflects glacial conditions during MIS 10. The intermediate values observed within the $\mathrm{MS}, \mathrm{Mn} / \mathrm{Fe}$ and $\mathrm{Si} / \mathrm{Ti}$ series at $\sim 336.5 \mathrm{ka}$ are interpreted as increased input of relatively unweathered material from the catchment, possibly associated with changing wind conditions or snow cover. Such factors could, respectively, mediate the amount of material deposited onto the lake surface and subsequent ablation into the lake. Fluvial deposition below a permanent ice-cover could also explain these variations, as described by Melles et al. (2012). Regardless of the transport mechanism, it is likely that the low SAR magnifies even minor changes to sediment input or sources thus amplifying the apparent climatic variability. The TOC and BSi records do not indicate an increase in biological productivity at this time, suggesting persistent ice-cover. This period is therefore interpreted as a mild interstadial rather than the onset of MIS 9.

All proxies other than BSi exceed glacial levels (including the interstadial period) at $\sim 335.5 \mathrm{ka}$, however, the climatic amelioration implied at this stage is probably magnified

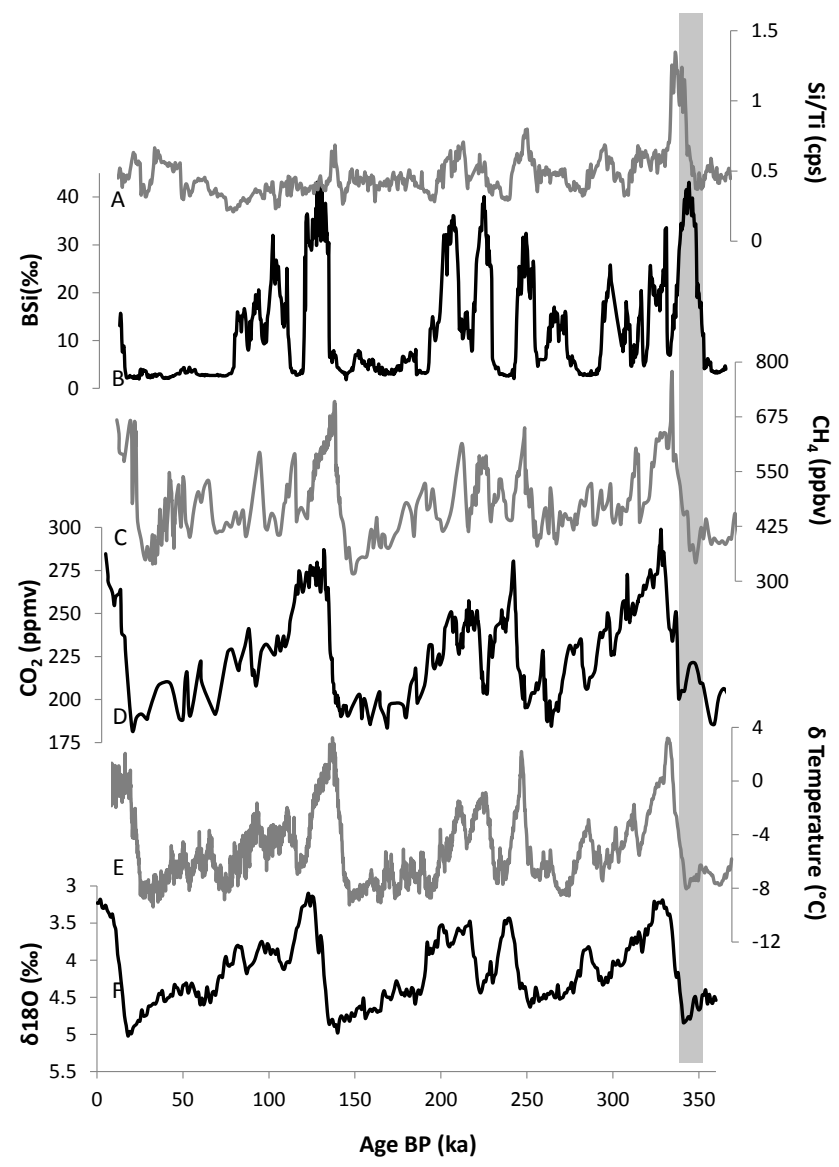

Fig. 3. Long-term proxy records showing the relative intensity of MIS 9 compared to more recent interglacial periods, including (A) Si/Ti records from Lake El'gygytgyn (Melles et al., 2012), (B) BSi records from Lake Baikal (Prokopenko et al., 2006); (C) $\mathrm{CH}_{4}$ concentrations in ice cores from Vostok (Petit et al., 1999); (D) $\mathrm{CO}_{2}$ concentrations in the Vostok ice core (Barnola et al., 2003); (E) variations in air temperature inferred from deuterium (Petit et al., 1999); and (F) the stacked $\delta^{18} \mathrm{O}$ record (Lisiecki and Raymo, 2005). The grey column represents the MIS9-10 transition period studied within this paper.

by the low SAR. The timing of this increase is consistent with the onset of MIS 9 at 335 ka suggested by D'Anjou et al. (2012). The small increase in the TOC values indicates a biological response, potentially stimulated by both a warmer climate and the associated input of organic matter from the catchment, but offset by higher rates of decomposition of organic matter within the water column and sediments. The implied trend towards milder climatic conditions continues until $\sim 333 \mathrm{ka}$. A large shift in the SAR observed at $\sim 334.5 \mathrm{ka}$ suggests that a major threshold has been crossed, and may represent the establishment of lake ice-free conditions during the summer periods. This is consistent with the BSi record from Lake Baikal which indicates MIS 9 commences at $\sim 334 \mathrm{ka}$ (Prokopenko et al., 2001) (Fig. 3). 
The dramatic increase in $\mathrm{BSi}$ at $\sim 334 \mathrm{ka}$ probably reflects climate-related increases in temperature and light combined with additional stimulation of bioproductivity by related changes in other environmental variables, such as vegetation, snow cover, and precipitation. For example, a small increase in temperature would result in earlier melting of snow and ice cover on the lake, both of which would further increase primary productivity. It is predicted that a 3 degree increase in temperature could extend the length of icefree conditions in European lakes by between 50 and 130 days depending on the geographical location (Thompson et al., 2005). This would represent a significant increase in the summer growth period given that, under current climatic conditions, Lake El'gygytgyn is ice-free for approximately 12 weeks per year (Nolan and Brigham-Grette, 2007). A temperature increase could also reduce snow cover in the surrounding catchment, and thereby affect the depth of permafrost and the active layer thereof, thus influencing water and nutrient regimes within catchment soils and, consequently, fluxes into the lake (Kawahigashi et al., 2004). Given such processes are likely to have also influenced the BSi values, quantitative estimates of temperature cannot be determined from the BSi values.

The BSi values observed during MIS 9 are higher than those seen within the penultimate interglacial period (Cunningham et al., 2013) thereby suggesting that more favourable climatic conditions existed during MIS 9. This is consistent with data from Lake Baikal (Fig. 3), where both BSi values and diatom abundances are higher during MIS 9 than in subsequent interglacials (Khursevish et al., 2001; Prokopenko et al., 2006; Fig. 3). Similarly total pollen abundances at Lake Baikal were higher, further suggesting more favourable climatic conditions during MIS 9 than at any time since (Shichi et al., 2007). Several other climatic records also suggest temperatures were higher during MIS 9 than in current interglacial, including ice core data from the Antarctic (Watanabe et al., 2003; Jouzel et al., 2007) and benthic foraminifera oxygen isotopes from the eastern equatorial pacific (Shackleton et al., 1990).

Insolation alone does not explain these results, as insolation at $65^{\circ} \mathrm{N}$ was not at its highest level of the past $350 \mathrm{ka}$. Instead, modelling results suggest increased warming occurred during MIS 9 because greenhouse gas concentrations reinforced the insolation changes (Yin and Berger, 2012). The carbon dioxide and methane records from Vostok show a similar pattern to the BSi values presented here (Fig. 3), with the lowest levels recorded early in MIS 10 rather than immediately preceding the rapid increase to MIS 9 interglacial conditions (Barnola et al., 2003). In contrast, the temperature record from Vostok follows the more typical saw tooth pattern (Fig. 3) whereby warming lags behind the increase in carbon dioxide (Petit et al., 1999). This provides further support for the hypothesis that climatic changes during this transition were initiated in the tropics or Northern Hemisphere, causing increasing global carbon dioxide concentrations, which later resulted in increased temperatures within the Antarctic (Kawamura et al., 2007).

\section{Conclusions}

The sediment record from Lake El'gygytgn clearly provides valuable information about past climates within the understudied Arctic region. The first high-resolution records of Transition IV from a terrestrial Arctic setting suggest the occurrence of a short interstadial period prior to deglaciation. BSi records lag behind the geochemical proxies analysed in this study suggesting that the biological response to warming may have been mediated through other processes such as nutrient input. Given the amplitude of change in the BSi record, it seems likely that local or regional feedback mechanisms are also influencing bioproductivity at this time possibly indicating a non-linear response of Arctic climate to external forcing. Finally, the disparities observed between the BSi and $\mathrm{Si} / \mathrm{Ti}$ records caution against using $\mathrm{Si} / \mathrm{Ti}$ as a surrogate for traditional BSi analyses.

Acknowledgements. The authors would like to thank Martin Melles and Julie Brigham-Grette for their vision and leadership on the El'gygytgyn project. We would also like to thank the participants of the spring campaign of the Lake El'gygytgyn expedition 2003 for the recovery of the sediment core (Lz1024) used in this study. Thanks also go to Annika Holmgren, Jan Åberg, Carin Olafsson, and Tomas Westin for laboratory assistance. Funding was provided by the German Federal Ministry for Education and Research (BMBF; grant no. 03G0586A, B), the German Research Foundation (DFG, JU 465/2-1), FORMAS and Vetenskapsrådet. This research was also supported by the Climate Impacts Research Centre (Umeå University) who provided salary to Laura Cunningham and Peter Rosén. The authors thank their colleagues for continuing support and discussion around the coffee breaks. The editor thanks X. Y. Furore and another referee for assisting in evaluating this paper.

Edited by: P. Minyuk

\section{References}

ACIA: Impacts of a Warming Arctic, Cambridge University Press, Cambridge, 140 pp., 2004.

Alley, R. B.: The Younger Dryas Cold Interval As Viewed From Central Greenland, Quaternary Sci. Rev., 19, 213-226, 2000.

Barnola, J. M., Raynaud, D., Lorius, C., and Barkov, N. I.: Historical $\mathrm{CO}_{2}$ Record from the Vostok Ice Core, in: Trends: A Compendium of Data on Global Change. Carbon Dioxide Information Analysis Center, Oak Ridge National Laboratory, US Department of Energy, Oak Ridge, Tenn., USA, 2003

Bauch, H. A. and Erlenkeuser, H.: A "critical" climatic evaluation of last interglacial (MIS 5e) records from the Norwegian Sea, Polar Res., 27, 135-151, 2008.

Bauch, H. A., Kandiano, E. S., Helmke, J., Andersen, N., RosellMele, A., and Erlenkeuser, H.: Climatic bisection of the last 
interglacial warm period in the Polar North Atlantic, Quaternary Sci. Rev., 30, 1813-1818, 2011.

Blass, A., Bigler, C., Grosjean, M., and Sturm, M.: Decadal-scale autumn temperature reconstruction back to $\mathrm{AD} 1580$ inferred from the varved sediments of Lake Silvaplana (southeastern Swiss Alps), Quaternary Res., 68, 184-195, 2007.

Brigham-Grette, J., Melles, M., Minyuk, P., and Party, S.: Overview and significance of a $250 \mathrm{ka}$ paleoclimate record from El'gygytgyn Crater Lake, NE Russia, J. Paleolimnol., 37, 1-16, 2007.

Brown, E. T., Johnson, T. C., Scholz, C., Cohen, A. S., and King, J. W.: Abrupt change in tropical African climate linked to the bipolar seesaw over the past 55,000 years, Geophys. Res. Lett., 34, L20702, doi:10.1029/2007GL031240, 2007.

Cherapanova, M. V., Snyder, J. A., and Brigham-Grette, J.: Diatom stratigraphy of the last $250 \mathrm{ka}$ at Lake El'gygytgyn, northeast Siberia, J. Paleoclim., 37, 155-162, 2007.

Cremer, H. and Wagner, B.: The diatom flora in the ultraoligotrophic Lake EI'gygytgyn, Chukotka, Polar Biol., 26, 105$114,2003$.

Croudace, I. W., Rindby, A., and Rothwell, R. G.: ITRAX: description and evaluation of a new multi-function X-ray core scanner, in: Rothwell, R. G., New Techniques in Sediment Core Analysis. Geological Society, London, Special Publications, 267, 51-63, 2006.

Cunningham, L., Vogel, H., Nowaczyk, N. R., Wennrich, V., Juschus, O., Persson, P., and Rosen, P.: Climatic variability during the last interglacial inferred from geochemical proxies in the Lake El'gygytgyn sediment record, Palaeogeogr. Palaeocli. Palaeoecol., submitted, 2013.

D’Anjou, R. M., Wei, J. H., Castañeda, I. S., Brigham-Grette, J., Petsch, S. T., and Finkelstein, D. B.: High-latitude environmental change during MIS 8-12: biogeochemical evidence from Lake El'gygytgyn, Far East Russia, Clim. Past Discuss., 8, 4745-4777, doi:10.5194/cpd-8-4745-2012, 2012.

Frank, U., Nowaczyk, N. R., Minyuk, P., Vogel, H., Rosén, P., and Melles, M.: A $350 \mathrm{kyr}$ record of climate change from Lake El'gygytgyn, Far East Russian Arctic: refining the pattern of climate modes by means of cluster analysis, Clim. Past Discuss., 8 , 5109-5132, doi:10.5194/cpd-8-5109-2012, 2012.

Holland, M. M. and Bitz, C. M.: Polar amplification of climate change in coupled models, Clim. Dynam., 21, 221-232, 2003.

IPCC: Climate Change 2007: The Physical Science Basis. Contribution of Working Group I to the Fourth Assessment Report of the Intergovernmental Panel on Climate Change, edited by: Solomon, S., Qin, D., Manning, M., Chen, Z., Marquis, M., Averyt, K. B., Tignor, M., and Miller, H. L., Cambridge University Press, Cambridge, United Kingdom and New York, NY, USA, 996 pp., 2007.

Johnsen, S. J., Dahl Jensen, D., Gundestrup, N., Steffensen, J. P., Clausen, H. B., Miller, H., Masson-Delmotte, V., Sveinbjornsdottir, A. E., and White, J.: Oxygen isotope and palaeotemperature records from six Greenland ice-core stations: Camp Century, Dye-3, GRIP, GISP2, Renland and North GRIP, J. Quaternary Sci., 16, 299-307, 2001.

Jouzel, J., Masson-Delmotte, V., Cattani, O., Dreyfus, G., Falourd, S., Hoffmann, G., Minster, B., Nouet, J., Barnola, J. M., Chappellaz, J., Fischer, H., Gallet, J. C., Johnsen, S., Leuenberger, M., Loulergue, L., Luethi, D., Oerter, H., Parrenin, F., Raisbeck,
G., Raynaud, D., Schilt, A., Schwander, J., Selmo, E., Souchez, R., Spahni, R., Stauffer, B., Steffensen, J. P., Stenni, B., Stocker, T. F., Tison, J. L., Werner, M., and Wolff, E.: Orbital and millennial Antarctic climate variability over the past 800,000 years, Science, 317, 793-796, 2007.

Kawahigashi, M., Kaiser, K., Kalbitz, K., Rodionov, A., and Guggenberger, G.: Dissolved organic matter in small streams along a gradient from discontinuous to continuous permafrost, Global Change Biol., 10, 1576-1586, 2004.

Kawamura, K., Parrenin, F., Lisiecki, L., Uemura, R., Vimeux, F., Severinghaus, J. P., Hutterli, M. A., Nakazawa, T., Aoki, S., Jouzel, J., Raymo, M. E., Matsumoto, K., Nakata, H., Motoyama, H., Fujita, S., Goto-Azuma, K., Fujii, Y., Watanabe, O., and Layer, P.: Argon-40/argon-39 age of the El'gygytgyn impact event, Chukotka, Russia, Meteorol. Planet. Sci., 35, 591-599, 2000.

Kawamura, K., Parrenin, F., Lisiecki, L. Uemura, R., Vimeux, F., Severinghaus, J. P., Hutterli, M. A., Nakazawa, T., Aoki, S., Jouzel, J., Raymo, M., Matsumoto, K., Nakata, H., Motoyama, H., Fujita, S., Goto-Azuma, K., Fujii, Y., and Watanabe, O.: Northern Hemisphere forcing of climatic cycles in Antarctica over the past 360,000 years, Nature, 448, 912-916, 2007.

Khursevich, G. K., Karabanov, E. B., Prokopenko, A. A., Williams, D. F., Kuzmin, M. I., Fedenya, S. A., and Gvozdkov, A. A.: Insolationregime in Siveria as a major factor controlling diatom production in Lake Baikal during the last 800,000 years, Quaternary Int., 80, 47-58, 2001.

Layer, P. W.: Argon-40/Argon-39 age of the El'gygytgyn impact event, Chukotka, Russia, Meteorol. Planet. Sci., 35, 591-599, 2000.

Lisiecki, L. E. and Raymo, M. E.: A Pliocene-Pleistocene stack of 57 globally distributed benthic D18O records, Paleoceanography, 20, PA1003, doi:10.1029/2004PA001071, 2005.

Loizeau, J., Span, D., Coppee, V., and Dominik, J: Evolution of the trophic state of Lake Annecy (eastern France) since the last glaciation as indicated by iron, manganese and phosphorus speciation, J. Paleolimnol., 25, 205-214, 2001.

Lozhkin, A. V., Anderson, P. M., Matrosova, T. V., and Minyuk, P. S.: The pollen record from El'gygytgyn Lake: implications for vegetation and climate histories of northern Chukotka since the late middle Pleistocene, J. Paleolimnol., 37, 135-153, 2007.

McKay, N. P., Kaufman, D. S., and Michelutti, N.: Biogenic silica concentration as a high-resolution, quantitative temperature proxy at Hallet Lake, south-central Alaska, Geophys. Res. Lett., 35, L05709, doi:10.1029/2007GL032876, 2008.

Melles, M., Minyuk, P., Brigham-Grette, J., and Juschus O.: The Expedition El'gygytgyn Lake 2003 (Siberian Arctic), Reports of the Polar and Marine Institute 509, Alfred Wegner Istitute, Bremerhaven, 139 p., 2005.

Melles, M., Brigham-Grette, J., Glushkova, O. Y., Minyuk, P. S., Nowaczyk, N. R., and Hubberten, H. W.: Sedimentary geochemistry of core PG1351 from Lake El'gygytgyn - a sensitive record of climate variability in the East Siberian Arctic during the past three glacial-interglacial cycles, J. Paleolimnol., 37, 89-104, 2007.

Melles, M., Brigham-Grette, J., Minyuk, P., Koeberl, C., Andreev, A., Cook, T., Fedorov, G., Gebhardt, C., Haltia-Hovi, E., Kukkonen, M., Nowaczyk, N., Schwamborn, G., Wennrich, V., and El'gygytgyn Scientific Party: The El'gygytgyn Scientific 
Drilling Project - conquer-ing Arctic challenges through continental drilling, Scientific Drilling, 11, 29-40, 2011.

Melles, M., Brigham-Grette, J., Minyuk, P. S., Nowaczyk, N. R., Wennrich, V., DeConto, R. M., Anderson, P. M., Andreev, A. A., Coletti, A., Cook, T. L., Haltia-Hovi, E., Kukkonen, M., Lozhkin A. V., Rosén, P., Tarasov, P., Vogel, H., and Wagner, B.: 2.8 Million Years of Arctic Climate Change from Lake El'gygytgyn, NE Russia, Science, 337, 315-320, 2012.

Natori, Y., Haneda, A., and Suzuki, Y.: Vertical and seasonal differences in biogenic silica dissolution in natural seawater in Suruga Bay, Japan: Effects of temperature and organic matter, Mar. Chem., 102, 230-241, 2006.

Niessen, F., Gebhardt, A. C., Kopsch, C., and Wagner, B. Seismic investigation of the El'gygytgyn impact crater lake (Central Chukotka, NE Siberia): preliminary results, J. Paleolimnol., 37, 49-63, 2007.

Nolan, M. and Brigham-Grette, J.: Basic hydrology, limnology, and meteorology of modern Lake El'gygytgyn, Siberia, J. Paleolimnol., 37, 17-35, 2007.

Nowaczyk, N. R., Minyuk, P., Melles, M., Brigham-Grette, J., Glushkova, O., Nolan, M., Lozhkin, A. V., Stetsenko, T. V., Andersen, P. M., and Forman, S. L.: Magnetostratigraphic results from impact crater Lake El'gygytgyn, northeastern Siberia: a 300 kyr long high-resolution terrestrial palaeoclimatic record from the Arctic, Geophys. J. Int., 150, 109-126, 2002.

Nowaczyk, N. R., Melles, M., and Minyuk, P.: A revised age model for core PG1351 from Lake El'gygytgyn, Chukotka, based on magnetic susceptibility variations tuned to northern hemisphere insolation variations, J. Paleolimnol., 37, 65-76, 2007.

Oppo, D. W., McManus, J. F., and Cullen, J. L.: Abrupt climate events 500,000 to 340,000 years ago: Evidence from subpolar North Atlantic sediments, Science, 279, 1335-1338, 1998.

Petit, J. R., Jouzel, J., Raynaud, D., Barkov, N. I., Barnola, J. M., Basile, I., Bender, M., Chappellaz, J., Davis, M., Delaygue, G., Delmotte, M., Kotlyakov, V. M., Legrand, M., Lipenkov, V. Y., Lorius, C., Pepin, L., Ritz, C., Saltzman, E., and Stievenard, M.: Climate and atmospheric history of the past 420,000 years from the Vostok ice core, Antarctica, Nature, 399, 429-436, 1999.

Prokopenko, A. A., Karabanov, E. B., Williams, D. F., Kuzmin, M. I., Shackleton, N. J., Crowhurst, S. J., Peck, J. A., Gvozdkov, A. N., and King, J. W.: Biogenic silica record of the Lake Baikal response to climatic forcing during the Brunhes, Quaternary Res., 55, 123-132, 2001.

Prokopenko, A. A., Hinnov, L. A., Williams, D. F., and Kuzmin, M. I.: Orbital forcing of continental climate during the Pleistocene: a complete astronomically tuned climatic record from Lake Baikal, SE Siberia, Quaternary Sci. Rev., 25, 3431-3457, 2006.

Ryves, D. B., Jewson, D. H., Sturm, M., Battarbee, R. W., Flower, R. J., Mackay, A. W., and Granin, N. G.: Quantitative and qualitativerelationships between planktonic diatom communities and diatom assemblages in sedimenting material and surface sediments in Lake Baikal, Siberia, Limnol. Oceanogr., 48, 16431661, 2003.
Rosén, P., Vogel, H., Cunningham, L., Hahn, A., Hausman, S., Pientiz, R., Wagner, B., and Persson, P.: A globally applicable model for quantitative determination of lake sediment properties using Fourier transform infrared spectroscopy, Environ. Sci. Technol., 45, 8858-8865, 2011.

Serreze, M. C. and Francis, J. A.: The Arctic amplification debate, Clim. Change, 76, 241-264, 2006.

Shackleton, N. J., Berger, A., and Peltier, W. R.: An alternative astronomical calibration of the lower Pleistocene timescale based on ODP Site 677, Trans. Roy. Soc., Edinburgh, Earth Sci., 81, 251-261, doi:10.1017/S0263593300020782, 1990.

Shichi, K., Kawamuro, K., Takahara, H., Hase, Y., Maki, T., and Miyoshi, N.: Climate and vegetation changes around Lake Baikal during the last 350,000 years, Palaeogeogr., Palaeocli., 248, 357375, 2007.

Siddall, M., Stocker, T. F., Blunier, T., Spahni, R., McManus, J. F., and Bard, E.: Using a maximum simplicity paleoclimate model to simulate millennial variability during the last four glacial periods, Quaternary Sci. Rev., 25, 3185-3197, 2006.

Sveinbjornsdottir, A. E. and Johnsen, S. J.: Paleotemperature reconstruction from Greenland deep ice-cores, Natturufraedingurinn, 82, 135-145, 2012.

Snowball, I. F.: Geochemical control of magnetite dissolution in subarctic lakes sediments and the implications for environmental magnetism, J. Quaternary Sci., 8, 339-346, 1993.

Snyder, J. A., Cherepanova, M. V., and Bryan, A.: Dynamic diatom response to changing climate $0-1.2 \mathrm{Ma}$ at Lake El'gygytgyn, far east Russian Arctic, Clim. Past Discuss., 8, 4601-4624, doi:10.5194/cpd-8-4601-2012, 2012.

Thompson, R., Price, D., Cameron, N., Jones, V., Bigler, C., Rosen, P., Hall, R. I., Catalan, J., Garcia, J., Weckstrom, J., and Korhola, A.: Quantitative calibration of remote mountain-lake sediments as climatic recorders of air temperature and ice-cover duration, Arct Antarct, Alp. Res., 37, 626-635, 2005.

Vogel, H., Rosen, P., Wagner, B., Melles, M., and Persson, P..: Fourier transform infrared spectroscopy, a new cost-effective tool for quantitative analysis of biogeochemical properties in long sediment cores, J. Paleolimnol., 40, 689-702, 2008.

Watanabe, O., Jouzel, J., Johnsen, S., Parrenin, F., Shoji, H., and Yoshida, N.: Homogenous climate variability across East Antarctica over the past three glacial cycles, Nature, 422, 509-512, 2003.

Wersin, P., Höhener, P., Giovanoli, R., and Stumm, W.: Early diagenetic influences on iron transformations in a freshwater lake sediment, Chem. Geol., 90, 233-252 1991.

Wolff, E.: Chemical signals of past climate and environment from polar ice cores and firn air, Chem. Soc. Rev., 41, 6247-6258, 2012.

Yin, Q. Z. and Berger, A.: Individual contribution of insolation and $\mathrm{CO}_{2}$ to the interglacial climates of the past 800,000 years. Clim. Dynam., 38, 709-724, 2012. 